\title{
Plant diversity in integrated crop-livestock systems increases the soil enzymatic activity in the short term ${ }^{1}$
}

\author{
Aline de Jesus Franco ${ }^{2}$, Ana Paula Valadares da Silva², Amanda Beatriz Silva Souza ${ }^{3}$, Rafael Loverde Oliveira ${ }^{3}$, \\ Éder Rodrigues Batista ${ }^{2}$, Edicarlos Damacena de Souza ${ }^{3}$, Aline Oliveira Silva ${ }^{2}$, Marco Aurélio Carbone Carneiro ${ }^{2}$
}

\section{ABSTRACT}

Integrated crop-livestock systems (ICLS) intercropped in the pasture phase promote alterations in the dynamics of soil attributes, among them the enzymatic activity. This study aimed to evaluate soil enzymatic and microbial activities, following the implementation of ICLS with increased plant diversity during the pasture phase. The study consisted of soybean cultivation at season and pasture with different diversity levels in the off-season: very low - monocropped Urochloa brizantha cv. BRS Paiaguás with no animal entry; low - monocropped Paiaguás; medium - Paiaguás and cowpea bean (Vigna unguiculata); high - Paiaguás, cowpea bean and niger (Guizotia abyssinica); very high - Paiaguás, cowpea bean, niger, buckwheat (Fogopyrum esculentum) and forage turnip (Raphanus sativus). The introduction of plants from different families, associated to grazing, positively affected the enzymatic activities of acid phosphatase, $\beta$-glucosidase and urease. In relation to microbial biomass carbon and basal respiration, there were no effects from the treatments. Therefore, among the evaluated biochemical soil attributes, the activities of some soil enzymes were more sensitive in demonstrating, in the short term, the positive effects of the increased plant variety in the ICLS pasture phase.

KEYWORDS: Brazilian Savanna, soil enzymes, nutrient cycling, no-tillage.

\section{INTRODUCTION}

Brazil is the second major soybean (Glycine max) producer in the world, whilst Mato Grosso is its state with the largest production, which was 32.12 million tons in the 2018/2019 crop season (Conab 2019). It is fundamental to adopt techniques that guarantee the sustainability of

\section{RESUMO}

Diversidade de plantas em sistemas integrados de produção agropecuária incrementa a atividade enzimática do solo no curto prazo

Sistemas integrados de produção agropecuária (SIPA) com consórcios na fase pastagem promovem alterações na dinâmica de atributos dos solos, entre eles a atividade enzimática. Objetivouse avaliar as atividades microbiana e enzimática do solo, após implantação de SIPA com aumento da diversidade de plantas na fase pastagem. O estudo consistiu no cultivo de soja na safra e pasto com diferentes níveis de diversidade na safrinha: muito baixa - Urochloa brizantha $\mathrm{cv}$. BRS Paiaguás cultivado solteiro sem entrada de animais; baixa - Paiaguás em cultivo solteiro; média - Paiaguás e feijão caupi (Vigna unguiculata); alta - Paiaguás, feijão caupi e niger (Guizotia abyssinica); muito alta - Paiaguás, feijão caupi, niger, trigo mourisco (Fogopyrum esculentum) e nabo forrageiro (Raphanus sativus). A introdução de plantas de diferentes famílias, associadas ao pastejo, afetaram positivamente as atividades enzimáticas da fosfatase ácida, $\beta$-glicosidase e urease. Em relação aos atributos carbono da biomassa microbiana e respiração basal, não houve efeito dos tratamentos. Portanto, dentre os atributos bioquímicos do solo avaliados, as atividades de algumas enzimas do solo foram mais sensíveis em demonstrar, em curto período de tempo, os efeitos positivos do aumento da diversidade de plantas na fase de pastagem do SIPA.

PALAVRAS-CHAVE: Cerrado, enzimas do solo, ciclagem de nutrientes, plantio direto.

soybean cultivation through the use of integrated crop-livestock systems, which allow for a better cultivated area exploitation.

Integrated crop-livestock systems (ICLS) consist of associations between commercial agricultural crops and animal pastures, concomitantly or sequentially, that require sinergic interactions between these associations, in order to obtain

${ }^{1}$ Received: June 24, 2020. Accepted: Sep. 02, 2020. Published: Oct. 23, 2020. DOI: 10.1590/1983-40632020v5064026.

${ }^{2}$ Universidade Federal de Lavras, Departamento de Ciência do Solo, Setor de Biologia, Microbiologia e Processos Biológicos do Solo, Lavras, MG, Brasil.E-mail/ORCID: alinefrancoagro@outlook.com/0000-0001-5617-5369, anapaulavaladaresdasilva@gmail.com/0000-0001-5300-7212, eder.pgagri@gmail.com/0000-0003-3904-7749, alineoliveirasilva6@gmail.com/0000-0003-0317-4797,marcocarbone@ufla.br/0000-0003-4349-3071.

${ }^{3}$ Universidade Federal de Rondonópolis, Rondonópolis, MT, Brasil. E-mail/ORCID: amandabeatrizsilva@outlook.com.br/ 0000-0003-2620-7950, rafa-loverde@hotmail.com/0000-0002-5964-6565, edicarlos@ufr.edu.br/0000-0003-3719-8615. 
economic and environmental gain (Moraes et al. 2019). Agroecosystems formed via ICLS sustain revenue increases and face less economic risk, due to the diversity of obtained products, such as grains, fibers, biofuels and meat. Furthermore, the systems contribute to reducing the greenhouse gas emission, increasing the soil carbon (C) sequestration and maintaining water courses, among other benefits, making the agroecosystem more resilient and sustainable in the long term (Ryschawy et al. 2012, Peterson et al. 2018).

Plant diversity incorporated via ICLS provides numerous benefits to the soil, such as better nutrient utilization, increased carbon buildup, microbial activity and soil microorganism diversity, as well as decreased pests and diseases incidence (Blanco-Canqui et al. 2015, Carvalho et al. 2018, Laroca et al. 2018, Moraes et al. 2019). Therefore, a bigger diversity influences the microbial community present in the agroecosystem, as it is associated to the edaphoclimatic and functional conditions of the environment (Tilman 2001, Shigyo et al. 2019).

The soil microbiota plays a fundamental role in the sustenance of soil ecosystem services, because it presides over the maintenance of several important processes, such as decomposition, mineralization of organic waste, transformation of chemical elements, soil structuring and root symbiosis (Prober et al. 2015, Bashri et al. 2018). Decomposition and mineralization are processes fulfilled by released enzymes and, largely, by the microorganisms in the soil, which act upon organic and xenobiotic compounds, releasing energy and chemical elements that are then used by the microorganisms themselves, other soil organisms and by the plants' roots (Balota et al. 2014, Medeiros et al. 2017, Zhou \& Staver 2019). Therefore, enzymes are considered sensitive bioindicators in soil handling and use, and may be applied for monitoring the agroecosystems (Mendes et al. 2018).

Thus, the hypothesis in the present study is that the increase in functional plant diversity associated with animal grazing promotes an increase in the soil microbial activities, highlighting the increase of enzymatic activities involved in nutrient cycling. Therefore, the study aimed at evaluating the soil microbial and enzymatic activities in the short term, in integrated crop-livestock systems, with an increase in plant diversity during the grazing phase.

\section{MATERIAL AND METHODS}

The study was conducted at the Fazenda Girassol, located in Pedra Preta, Mato Grosso state, Brazil (16² $48^{\prime} 5121^{\prime \prime}$ S, 5404'1985'W and altitude of $732 \mathrm{~m}$ ). According to the Köppen classification, the climate is Aw, with an average annual temperature of $24.7^{\circ} \mathrm{C}$ and annual precipitation of $1,533 \mathrm{~mm}$. The soil is classified as a Dystrophic Red Oxisol, with the following chemical and textural characteristics: $\mathrm{pH}=5.6 ; \mathrm{Al}^{3+}=0.06 \mathrm{cmol} \mathrm{dm}^{-3} ; \mathrm{Ca}^{2+}=3.0 \mathrm{cmol} \mathrm{dm}^{-3}$; $\mathrm{Mg}^{2+}=1.08 \mathrm{cmol} \mathrm{dm}^{-3} ; \mathrm{K}=0.27 \mathrm{cmol} \mathrm{dm}^{-3} ; \mathrm{P}=$ $13 \mathrm{mg} \mathrm{dm}^{-3}$; CEC (pH 7) $=8.7 \mathrm{cmol}_{\mathrm{c}} \mathrm{dm}^{-3}$; base saturation $=57 \%$; organic matter $=43 \mathrm{~g} \mathrm{~kg}^{-1}$; clay $=450 \mathrm{~g} \mathrm{~kg}^{-1}$; silt $=360 \mathrm{~g} \mathrm{~kg}^{-1}$; and sand $=$ $190 \mathrm{~g} \mathrm{~kg}^{-1}$.

Before carrying out the experiment, the area had been cultivated for over 20 years with soybean at the season and corn or cotton during the off-season, with no fallow between harvests. In the five years prior to the experiment (2013-2018), the area was cultivated with no-tillage soybean and grasses of the Urochloa genus, in grazing with a stocking rate of 2.5 AU (Animal Unit) ha-1 ${ }^{-1}$ during the off-season, and no fallowing. The animals were removed 30 days prior to planting and the soybean was handled with recommended techniques for the region, inoculated with bacteria from the Bradyrhizobium genus, at a ratio of $2 \mathrm{~mL}$ for $1 \mathrm{~kg}$ of seeds, under no-tillage and fertilizing of $500 \mathrm{~kg} \mathrm{ha}^{-1}$ with NPK (00-18-18) before sowing, not fertilizing the pasture. The experiment took place in March 2018, after the soybean harvest.

After the soybean harvest, a soil sampling that analyzed the biochemical characteristics of the area took place before the experiment began, as the samples were collected in November 2017, at a depth of $10 \mathrm{~cm}$, during the soybean R1-R2 stages (flowering), at the rainy season (Table 1).

The experimental design was randomized blocks, with five treatments and three replications, totaling fifteen experimental plots, with 3.2 ha for each plot. The treatments consisted of the use of vegetable species during the off-season, under notillage, as it follows: very low diversity - no-tillage Urochloa brizantha cv. BRS Paiaguás without animal grazing; low diversity - no-tillage Paiaguás; medium diversity - no-tillage Paiaguás and cowpea bean (Vigna unguiculata); high diversity - notillage Paiaguás, cowpea bean and niger (Guizotia abyssinica); very high diversity - no-tillage Paiaguás, 
Table 1. Biochemical parameters characterizing the area before the experiment.

\begin{tabular}{|c|c|c|}
\hline Parameter/Unit & Quantity & CV $(\%)$ \\
\hline $\mathrm{MBC}\left(\mu \mathrm{g} \mathrm{g}^{-1}\right)$ & 311.32 & 11.91 \\
\hline SBR $\left(m g\right.$ C-CO ${ }_{2} \mathrm{~g}^{-1}$ soil h $\left.\mathrm{h}^{-1}\right)$ & 3.50 & 12.60 \\
\hline$q \mathrm{CO}_{2}\left(\mathrm{mg} \mathrm{C}-\mathrm{CO}_{2} \mu \mathrm{g}^{-1} \mathrm{MBC}\right)$ & 11.80 & 22.16 \\
\hline$q \operatorname{Mic}(\%)$ & 1.30 & 16.77 \\
\hline Acid phosphatase ( $\mu \mathrm{g} \rho$-nitrophenyl-phosphate $\mathrm{g}^{-1}$ soil $^{-1}$ ) & 901.42 & 11.01 \\
\hline$\beta$-glucosidase $\left(\mu \mathrm{g} \rho\right.$-nitrofenol $\mathrm{g}^{-1}$ soil $\left.^{-1}\right)$ & 430.80 & 23.03 \\
\hline Urease $\left(\mu \mathrm{g} \mathrm{NH}_{4}-\mathrm{N} \mathrm{g}^{-1}\right.$ soil h$\left.^{-1}\right)$ & 2.90 & 13.48 \\
\hline
\end{tabular}

MBC: microbial biomass carbon; SBR: soil basal respiration; $q \mathrm{CO}_{2}$ : metabolic quotient; $q$ Mic: microbial quotient.

cowpea bean, niger, buckwheat (Fogopyrum esculentum) and forage turnip (Raphanus sativus). In all the treatments, except for the very low diversity one, male bovines of the Nelore race, weighing 250$280 \mathrm{~kg}$, were used on the grazing phase. The animals were taken to the areas when the pasture (grasses) reached a medium height of $60 \mathrm{~cm}$, with a fixed stocking rate of $2 \mathrm{AU} \mathrm{ha}^{-1}$ and grazing for 75 days.

The sowing for the intercropping was carried out together, in rows, with precision sowing machines, according to the composition of each treatment. The cowpea planting was carried out with a coarse grain seeder, spacing of $45 \mathrm{~cm}$ and 5 seeds $\mathrm{m}^{-1}$, at a depth of $5 \mathrm{~cm}$. The rest of the seeds were sown with a continuous flow fine grain seeder and spacing of $17.5 \mathrm{~cm}$, with a mixture of all seeds of the intercropping, at a depth of $3 \mathrm{~cm}$. The amount of pure and viable seeds per ha was $10.0 \mathrm{~kg}$ for Paiaguás, $4.0 \mathrm{~kg}$ for niger, $10.0 \mathrm{~kg}$ for buckwheat, $3.0 \mathrm{~kg}$ for forage turnip and, in the case of cowpea, 5 seeds $\mathrm{m}^{-1}$ (about $22 \mathrm{~kg} \mathrm{ha}^{-1}$ ) were used.

The soil samples were collected in December 2018, at the R1-R2 stages (flowering) of soybean, in the rainy season. Each of the experimental plots had 12 sampling points to obtain the composed sample, in the layer of $0-10 \mathrm{~cm}$ of depth. The material was sent to the laboratory, sieved $(2 \mathrm{~mm})$ and stored at $4{ }^{\circ} \mathrm{C}$, until analysis. The period between receiving the samples in the lab and the analyses was of approximately four weeks.

The chemical, biological and biochemical analysis were fulfilled with the following methodologies: $\mathrm{pH}$ in water $(1: 2.5)$; phosphorus and potassium (Mehlich 1953); $\mathrm{Al}^{3+}, \mathrm{Ca}^{2+}$ and $\mathrm{Mg}^{2+}$ (McLean et al. 1958); texture (Bouyoucos 1951); total nitrogen by the Kjeldahl method (Joergensen \& Brookes 1990); total organic carbon (Walkley \& Black 1934); microbial biomass carbon (Vance et al. 1987); soil basal respiration (Alef \& Nannipiere 1995); metabolic quotient $\left(q \mathrm{CO}_{2}\right)$ (Anderson \& Domsch 1993); $\beta$-glucosidase enzyme activity (Eivazi \& Tabatabai 1988); acid phosphatase enzyme activity (Dick et al. 1997); urease enzyme activity (Tabatabai \& Bremner 1972); geometric mean of enzyme activities (Hinojosa et al. 2004); carbon use efficiency (Roller \& Schmidt 2015); and enzymatic potential conversion (Dick et al. 1997), as shown in the equation: $[(\mu \mathrm{g}$ PNP $) /(g$ of soil $\mathrm{x}$ time unit $)] \mathrm{x}$ $[(\mu \mathrm{g}$ nutrient $/ \mu \mathrm{mol}) /($ nutrient atomic mass $)]=\mu \mathrm{g}$ nutrient $\mathrm{g}^{-1}$ soil time ${ }^{-1}$.

The results were submitted to normality tests and, when compliant to normality and homoscedasticity, subsequently submitted to analysis of variance and Tukey tests, at $5 \%$ of probability, for comparison of means, and principal component analysis, using the v. 5.6 Sisvar (Ferreira 2011) and R (R Development Core Team 2019) softwares.

\section{RESULTS AND DISCUSSION}

Plant diversity associated to grazing influenced the soil after the deployment of the ICLS, with an increase in acid phosphatase, $\beta$-glucosidase and urease activities (Figure 1). There was an increase in the acid phosphatase enzyme activities in all areas, except the one without grazing, with values of 900-1,949 $\mu \mathrm{g} \rho$-nitrophenyl-phosphate $\mathrm{g}^{-1} \mathrm{dry} \mathrm{soil}^{-1}$ (Figure 1). Systems that integrated the highest number of plant species, such as medium, high and very high diversity, are the ones that exhibited the highest increases in this enzyme's activities $(70,75$ and $116 \%$, respectively), according to the mean value observed before the experiment, which was $901.42 \mu \mathrm{g}$ $\rho$-nitrophenyl-phosphate $\mathrm{g}^{-1}$.

Higher acid phosphatase activities may have guaranteed a better phosphorus availability for the 
a)

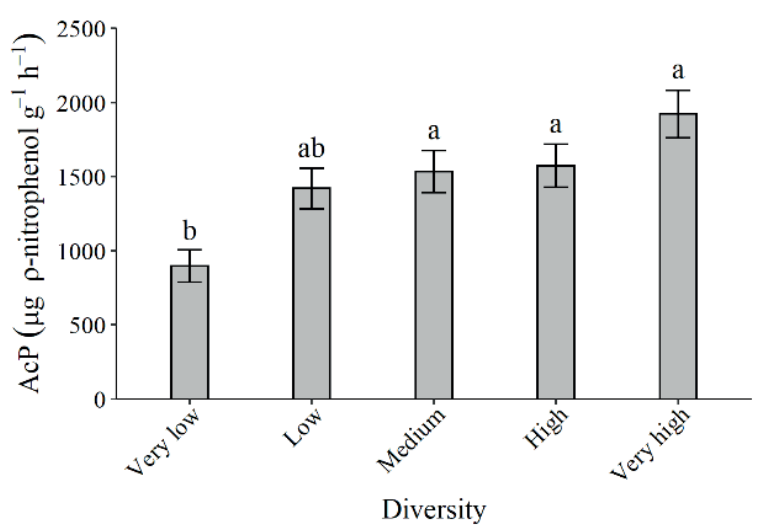

b)

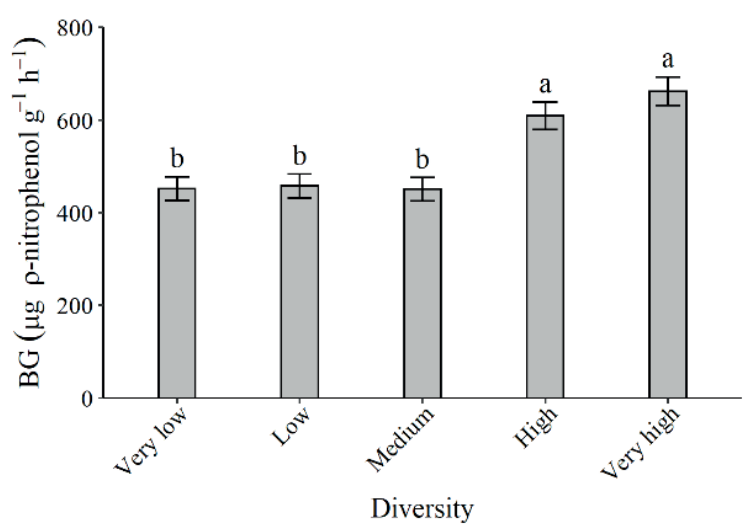

c)

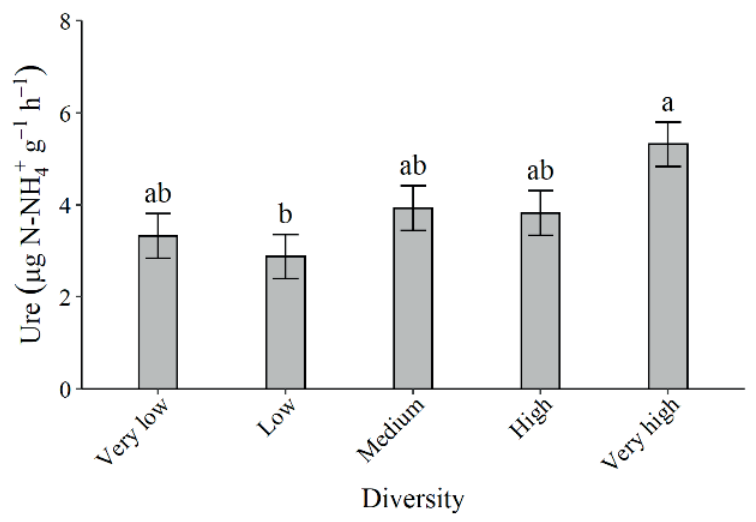

Figure 1. Acid phosphatase (AcP) (a), $\beta$-glucosidase (BG) (b) and urease (Ure) (c) enzyme activities in the soil, during the flowering of the soybean crop, after intercropping with plants via integrated crop-livestock system (means followed by the same letter do not differ among each other by the Tukey test at $5 \%$. Very low diversity: notillage Paiaguás without animal grazing; low diversity: no-tillage Paiaguás; medium diversity: no-tillage Paiaguás and cowpea bean; high diversity: no-tillage Paiaguás, cowpea bean and niger; very high diversity: no-tillage Paiaguás, cowpea bean, niger, buckwheat and forage turnip). subsequent soybean crop; thus, microorganisms are capable of increasing the soil productive capacity through nutrient cycling, rendering them readily available for the crop. In the case of phosphatases, they break up compounds such as phytates from decomposing organic compounds and readily release available phosphates that can be absorbed by plants (Dick et al. 1997). This increase in phosphatase activities via ICLS corroborates the results by Barbiere et al. (2019), who, by studying management techniques in the Brazilian South, discovered an increase in acid phosphatase activities in areas that showed a higher plant diversity at the second harvest. Studies carried out in the Cerrado (Brazilian Savanna) region have shown values for this enzyme ranging from 23 to 2,100 $\mu \mathrm{g}$ of p-nitrophenol $\mathrm{h}^{-1} \mathrm{~g}^{-1}$ dry soil (Mendes et al. 2003, Carneiro et al. 2009, Mankolo et al. 2012, Laroca et al. 2018, Barbiere et al. 2019), demonstrating that the values observed in this study are within the range found in the region.

An increase in the $\beta$-glucosidase activity was reported for all treatments, according to the mean values observed before the experiment took place (Figure 1), especially for the treatments with high and very high diversity, with increases of 42 and $54 \%$, respectively. This shows that $\beta$-glucosidase has a great sensitivity to detecting alterations in the functional diversity promoted by the systems, corroborating other studies based on no-tillage systems in the Brazilian Savanna (Matsuoka et al. 2003, Lopes et al. 2018, Sarto et al. 2020). The mean value for the $\beta$-glucosidase activity (Figure 1) was $527 \mu \mathrm{g} \rho$-nitrofenol $\mathrm{g}^{-1}$ dry soil $\mathrm{h}^{-1}$, staying at the recommended value range, which is $>225$ for the Brazilian Savanna region, in similar conditions (Mendes et al. 2018).

Both the quantity and quality of the residues deposited on the soil influence the decomposition status. The organic residues from grasses and intercroppings with legumes are of higher quality, that is, have a smaller $\mathrm{C}: \mathrm{N}$ ratio, as the insertion of different plant families promotes the diversifying of plant root systems, which, consequently, improves the diversity of the deposited residue. Thereby, the $\beta$-glucosidase activity is altered, due to the direct relation that the enzyme has with the hydrolysis of easy to decompose organic compounds, and is highly related to C sources (Passos et al. 2008). Stieven et al. (2014) studied ICLS in the same region (Mato Grosso, Brazil) and observed that this enzyme 
activity is directly related to, mainly, the quality of the organic residue added to the soil. In this context, the increase of $\beta$-glucosidase contributes not only to the decomposition of organic compounds, but also to the constitution of organic matter, which, subsequently, improves the soil chemical, physical and biological properties (Mendes et al. 2018). The very high diversity associated with grazing increased the urease activity by $83 \%$, in relation to the system without grazing (Figure 1). This may occur due to the insertion of urine, associated with cattle manure, and to an increased plant root diversity, which contribute to increase this enzyme activity (Stewart et al. 2016). An elevated urease activity favors the mineralization process that transforms organic $\mathrm{N}$ into inorganic $\mathrm{N}$, which is released into the soil and can be assimilated by plants of the crop, or even by microorganisms in the soil, being an advantageous source of $\mathrm{N}$ at low costs. Through ICLS, the soil microbiota increases (Souza et al. 2020), and, thereafter, so do microbial activities. Therefore, the association between animals and plants that have low $\mathrm{C}: \mathrm{N}$ ratios contributes to an increase in the urease activity (Lanna et al. 2010, Laroca et al. 2018).

The importance of enzymatic activities for the soil is not only due to their contribution in transforming nutrients, but also due to their participation in processes related to soil quality increase; in other words, the improvement of chemical, physical and biological attributes ( $\mathrm{Hu}$ et al. 2014). A soil management that favors the agroecosystem sustainability must offer more biological activities

a)

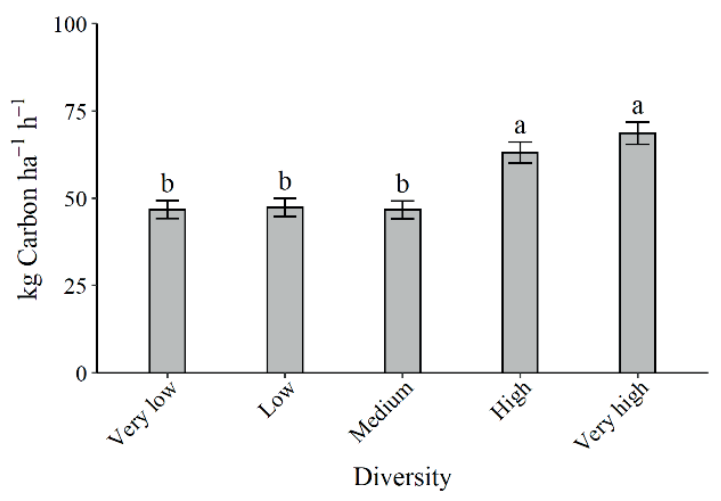

that reflect on the increased enzyme production and stabilization through increased soil matrix protection (Dick et al. 1997, Gupta et al. 2020).

An increased enzyme activity in systems with more plant diversity and cattle grazing, in the short term, demonstrates the importance of the active soil microbiota and its relation to soil fertility (Mendes et al. 2018, Gupta et al. 2020). Hence, the system with more plant diversity and cattle grazing shows a conversion potential (i.e., the transformation of organic compounds into inorganic compounds) of up to $69 \mathrm{~kg} \mathrm{ha}^{-1}$ of $\mathrm{C}$ through $\beta$-glucosidase and of $520 \mathrm{~kg} \mathrm{ha}^{-1}$ of $\mathrm{P}$ via acid phosphatase (Figures $2 \mathrm{a}$ and $2 b$ ). This indicates the benefits of increasing and mineralizing these chemical elements, reflecting on the system consolidation in the medium and long term, with more carbon, nitrogen and phosphorus in the soil microbial biomass and in the agroecosystem. The geometric mean enzymatic activity index, however, underwent no changes among the treatments (Table 2).

Biochemical attributes are considered sensitive bioindicators that can be used in soil monitoring, due to its management. Attributes such as microbial biomass carbon, soil basal respiration, metabolic quotient $\left(q \mathrm{CO}_{2}\right)$, microbial quotient $(q \mathrm{Mic})$ and carbon use efficiency have not been influenced by the functional diversity caused by the systems in the short term (Table 2). The lack of a short-term response given by these attributes has also been observed by Bonetti et al. (2018), who only obtained significant results two years after deploying an ICLS. The

b)

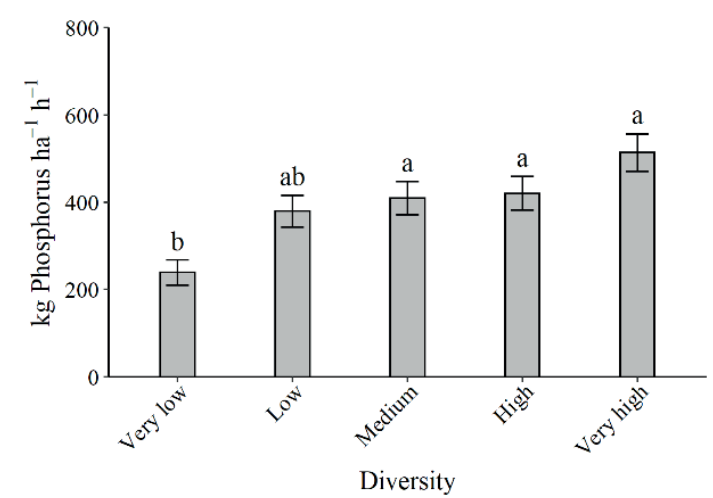

Figure 2. Carbon and phosphorus mineralization potential through the activity of $\beta$-glucosidase (a) and acid phosphatase (b), after intercropping in an integrated crop-livestock system (means followed by the same letter do not differ among each other by the Tukey test at $5 \%$. Very low diversity: no-tillage Paiaguás without animal grazing; low diversity: no-tillage Paiaguás; medium diversity: no-tillage Paiaguás and cowpea bean; high diversity: no-tillage Paiaguás, cowpea bean and niger; very high diversity: no-tillage Paiaguás, cowpea bean, niger, buckwheat and forage turnip). 
Table 2. Biochemical parameters for soybean cultivation, after intercropping with plants in integrated crop-livestock systems.

\begin{tabular}{lcccccc}
\hline \multicolumn{1}{c}{ Treatments } & $\begin{array}{c}\mathrm{MBC} \\
\mu \mathrm{g} \mathrm{g}^{-1}\end{array}$ & $\begin{array}{c}\mathrm{SBR} \\
\mathrm{mg} \mathrm{g}^{-1} \mathrm{~h}^{-1}\end{array}$ & $\begin{array}{c}q \mathrm{CO}_{2} \\
\mathrm{mg} \mathrm{C} \mathrm{CO}_{2} \mu \mathrm{gg}^{-1} \mathrm{MBC}\end{array}$ & $\begin{array}{c}q \mathrm{Mic} \\
\%\end{array}$ & $\begin{array}{c}\text { CUE } \\
\mu \mathrm{g} \mathrm{product} \mathrm{g}^{-1} \mathrm{~h}^{-1}\end{array}$ & $\begin{array}{c}\text { GMea } \\
\mu \mathrm{groduct} \mathrm{g}^{-1} \mathrm{~h}^{-1}\end{array}$ \\
\hline Very low diversity & $271.4^{\text {ns }}$ & $2.16^{\mathrm{ns}}$ & $9.12^{\text {ns }}$ & $0.96^{\text {ns }}$ & $0.990^{\text {ns }}$ & $0.016^{\text {ns }}$ \\
Low diversity & 292.03 & 2.26 & 7.78 & 1.12 & 0.992 & 0.012 \\
Medium diversity & 233.63 & 2.62 & 11.29 & 1.07 & 0.989 & 0.050 \\
High diversity & 280.96 & 2.37 & 9.09 & 1.19 & 0.990 & 0.039 \\
Very high diversity & 333.39 & 2.31 & 7.41 & 1.32 & 0.991 & 0.032 \\
CV (\%) & 24.50 & 16.01 & 29.90 & 23.02 & 0.270 & 59.680 \\
\hline
\end{tabular}

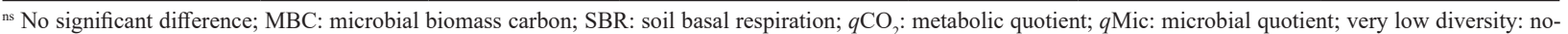
tillage Paiaguás without animal grazing; low diversity: no-tillage Paiaguás; medium diversity: no-tillage Paiaguás and cowpea bean; high diversity: no-tillage Paiaguás, cowpea bean and niger; very high diversity: no-tillage Paiaguás, cowpea bean, niger, buckwheat and forage turnip.

microbial biomass carbon and soil basal respiration are attributes commonly adopted for expressing the effects of soil management (Souza et al. 2014, Santos et al. 2019, Soleimani et al. 2019, Barros et al. 2020). The values for microbial biomass carbon and soil basal respiration (Table 2) are similar to the ones reported by other authors, regarding agricultural and pasture areas (46-500 $\mathrm{mg} \mathrm{C} \mathrm{kg}^{-1}$ of soil for microbial biomass carbon and 2.16-2.62 mg C-CO $\mathrm{kg}^{-1} \mathrm{~h}^{-1}$ for soil basal respiration), in the Brazilian Savanna region, specifically for clayey Oxisols (Kaschuk et al. 2010, Mendes et al. 2015).

Considering the microbial biomass carbon values before the deployment of the experiment as referential data [mean of $311.32 \mu \mathrm{g} \mathrm{C} \mathrm{g}^{-1}$ of soil, a value regarded as moderate via soil bioanalysis by Mendes et al. (2018)], it can be observed that the system with the highest functional diversity presented values superior to $7 \%$. Studies conducted by Bonetti et al. (2018) in the Brazilian Savanna, via ICLS, demonstrated that it was possible to obtain an increase of $23 \%$ for the microbial biomass carbon, in relation to the area with no grazing, during the first year, with significant effects only after two management years.

The values for microbial quotient did not differ among the observed areas, varying 0.96-1.32\% (Table 2). The ratio expressed by $q$ Mic indicates if the organic carbon is in equilibrium, increasing or decreasing (Anderson \& Domsch 1993). It can be observed that all the treatments presented low values, in relation to the treatment with the highest plant diversity and grazing (very high diversity), mainly the area with grasses and no grazing. Considering that this area (very low diversity) has a higher carbon content and lower microbial biomass carbon, the results indicate that there are pattern changes in the introduction of organic carbon, and that this treatment has an inferior effectiveness at converting microbial carbon into organic carbon, thus having a direct impact over the storing or accumulation of carbon over time.

Several studies reported that the plant diversity can affect microbial communities due to residue quality, increasing the exudate quantity and diversity in the soil, what affects the composition and structure of a microbial community (Lange et al. 2014, Cong et al. 2015, Couto et al. 2016, Araujo et al. 2019). A conservative management associated with plant diversity may provide an increased $\mathrm{C}$ accumulation in the long term, due to a higher organic matter contribution (Hoffmann et al. 2018).

Organic carbon content and total nitrogen were associated to the contribution of organic residues and organic matter in the soil during the deployment of the experiment. Plant diversity and grazing did not influence the total organic carbon behavior in the soil, but contributed to its maintenance, resembling the area before the experiment implementation (Figure 3). The total organic carbon varied $31-45 \mathrm{~g} \mathrm{~kg}^{-1}$, values considered adequate for the Brazilian Savanna soils with clayey textures (Sousa \& Lobato 2004). Total nitrogen only showed significant differences by being higher in the areas with no grazing (Figure 3). The areas with plant diversity and grazing presented a different nitrogen cycle dynamics, due to the quality of the residue present in these areas, acting similarly to what was observed in another study carried out under ICLS in the Brazilian Savanna by Souza et al. (2018).

This homogeneity, with low biomass and basal respiration responses among the treatments, is associated with the recent application of the experiment in an area via consolidated no-tillage system, being that neither grazing nor plant diversity 
a)

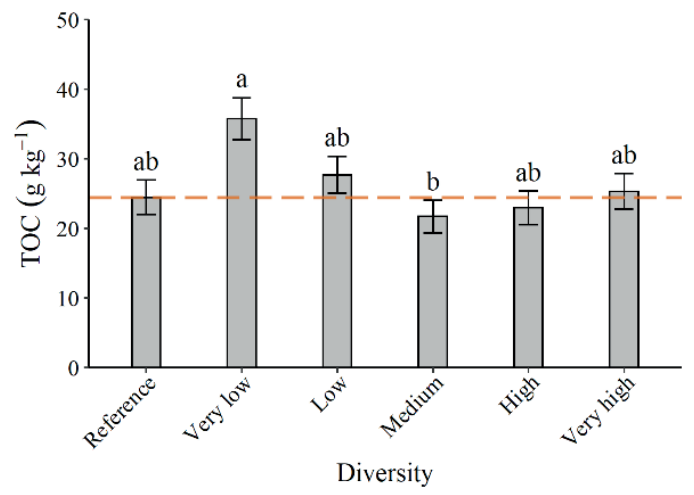

b)

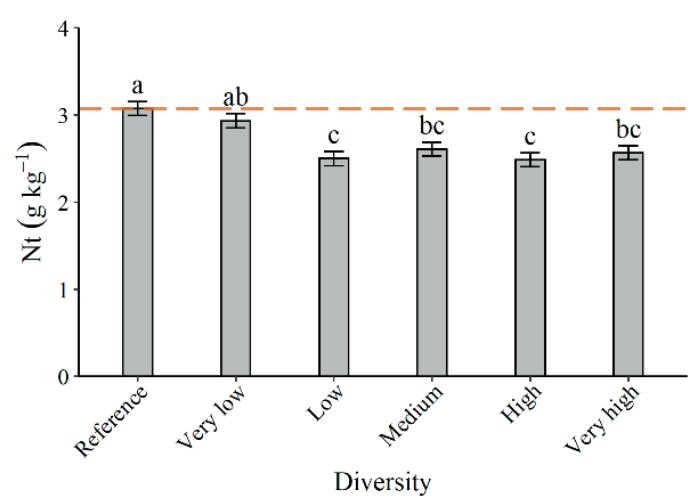

Figure 3. Total organic carbon contents (TOC) and total nitrogen (Nt) after intercropping with plants via integrated crop-livestock systems (similar letters in the treatment column do not differ by the Tukey test at $5 \%$. The reference corresponds to the mean before deploying the experiment. Very low diversity: no-tillage Paiaguás without animal grazing; low diversity: notillage Paiaguás; medium diversity: no-tillage Paiaguás and cowpea bean; high diversity: no-tillage Paiaguás, cowpea bean and niger; very high diversity: no-tillage Paiaguás, cowpea bean, niger, buckwheat and forage turnip. The line represents the baseline between the reference and the treatments).

have shown significant results, similarly to what was observed by Bonetti et al. (2018). Furthermore, it is known that the areas with moderate grazing intensity present a higher soil carbon sequestration potential. However, when the ICLS is implanted in an area with consolidated no-tillage, it shows little influence over the increase of the total soil organic carbon through grazing intensity, because the no-tillage system already has a positive carbon sequestration balance under these conditions (Cecagno et al. 2018).

The principal component analysis (PCA) confirmed the results obtained and allowed to demonstrate the difference between the evaluated treatments by means of biochemical soil attributes (Figure 4). The data variability in the two primary components (PC1 and PC2) corresponded to $74 \%$ of the total data variance. PC1 represented $49 \%$ and PC2 $25 \%$ of the total data variability. The geometric mean of enzyme activities and carbon use efficiency indexes did not present statistical differences among the treatments, but were important for the grouping analysis. Biochemical variables, such as acid phosphatase, urease, microbial quotient, soil basal respiration, metabolic quotient, geometric mean of enzyme activities and $\beta$-glucosidase, showed a higher correlation, which may be associated to the relation established between microbial biomass carbon and enzymatic activities, showing that these are sensitive indicators, regarding the changes in the soil management systems.

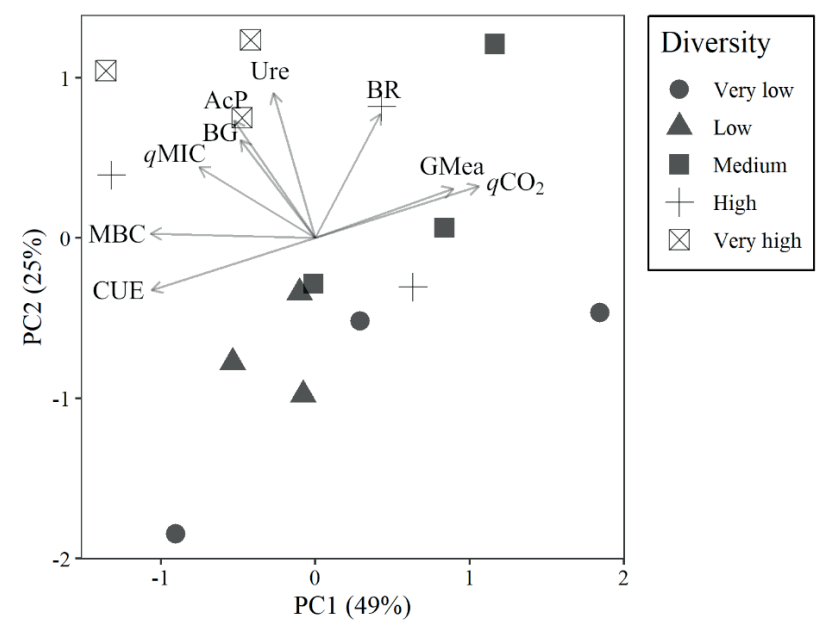

Figure 4. Analysis of the main biochemical attributes of the soybean cultivation soil, after intercropping with plants via integrated crop-livestock system (MBC: microbial biomass carbon; SBR: soil basal respiration; $q \mathrm{CO}_{2}$ : metabolic quotient; $q \mathrm{Mic}$ : microbial quotient; CUE: carbon use efficiency; GMea: geometric mean of enzyme activity; very low diversity: no-tillage Paiaguás without animal grazing; low diversity: notillage Paiaguás; medium diversity: no-tillage Paiaguás and cowpea bean; high diversity: no-tillage Paiaguás, cowpea bean and niger; very high diversity: no-tillage Paiaguás, cowpea bean, niger, buckwheat and forage turnip).

The results showed that the treatments with most plant diversity and grazing were the ones that greatly influenced the microbial biomass and 
activities (Figure 4). Another relevant aspect is that there was a high data dispersion in the treatment with low diversity and no animal grazing, what confirms the influence that diversity has on the functionality of the agroecosystem, being that it stimulates microbial activities in the soil, a fact mainly demonstrated by the soil enzymatic activity.

The microbial population in the soil requires a metabolic mechanism efficient at obtaining energy and nutrients through decomposition and mineralization processes, in order to sustain the microbial growth. For this, it produces metabolites and proteins that help to perform different processes in the soil. However, there is an energetic cost, so that the microbiota can perform these activities (Dick et al. 1997, Burns et al. 2013, Batista et al. 2020). That is, even though the release of enzymes and other catalytic agents in the soil is necessary to help the decomposition and mineralization, part of the products acquired from the reaction is used in the self-maintenance of soil microorganisms, and part is made available in the soil solution, able to be absorbed by plants. Hence, the soil microbiota can, at a given moment, determine how much energy it devotes to metabolite and protein production, as an investment proportion for future absorptions and microbial biomass biosynthesis.

Therefore, the energy devoted to the production of proteins (phosphatase, $\beta$-glucosidase and urease) manifests itself through the increased $\mathrm{P}, \mathrm{C}$ and $\mathrm{N}$ carrying or incorporation capacity into microbial biomass that these microorganisms have, which eventually reflects directly on the increase of microbial $\mathrm{C}$ values in the soil and will elevate the amount of $\mathrm{C}$ in the soil through stimulating the decomposition and stabilization of organic compounds. What is expected from a complex cultivation is the establishment of relations that stimulate microbial processes and ecosystemic duties carried out by soil microorganisms, in an attempt to guarantee a more functional environment.

\section{CONCLUSIONS}

1. The integrated crop-livestock system with high plant diversity, associated with grazing, promotes an increased soil enzyme activity, even in the short term;

2. Soil biological attributes such as microbial biomass carbon, basal respiration, microbial quotient, metabolic quotient, carbon use efficiency and geometric mean of enzyme activity are not sensitive to show changes caused by the integrated crop-livestock system deployed in the short term; 3. Soil enzymatic activities such as acid phosphatase, $\beta$-glucosidase and urease are sensitive in showing positive effects arising from the functional diversity of the integrated crop-livestock system in the short term.

\section{REFERENCES}

ALEF, K.; NANNIPIERI, P. Methods in applied soil microbiology and biochemistry. Lodon: Academic Press, 1995.

ANDERSON, J. P. E.; DOMSCH, K. H. The metabolic quotient of $\mathrm{CO}_{2}\left(q \mathrm{CO}_{2}\right)$ as a specific activity parameter to assess the effects of environmental condition, such as $\mathrm{pH}$, on the microbial of forest soil. Soil Biology and Biochemistry, v. 25, n. 3, p. 393-395, 1993.

ARAUJO, T. D. S.; GALLO, A. D. S.; ARAUJO, F. D. S.; SANTOS, L. C. D.; GUIMARÃES, N. D. F.; SILVA, R. F. D. Biomassa e atividade microbiana em solo cultivado com milho consorciado com leguminosas de cobertura. Revista de Ciências Agrárias, v. 42, n. 2, p. 347-357, 2019.

BALOTA, E. L.; MACHINESKI, O.; HAMID, K. I.; YADA, I. F.; BARBOSA, G. M.; NAKATANI, A. S.; COYNE, M. S. Soil microbial properties after long-term swine slurry application to conventional and no-tillage systems in Brazil. Science of the Total Environment, v. 490, n. 1, p. 397-404, 2014.

BARBIERE, M.; DOSSIN, M. F.; NORA, D. D.; SANTOS, W. B. D.; BEVILACQUA, C. B.; ANDRADE, N. D.; ANTONIOLLI, Z. I. Ensaio sobre a bioatividade do solo sob plantio direto em sucessão e rotação de culturas de inverno e verão. Revista de Ciências Agrárias, v. 42, n. 1, p. 121-130, 2019.

BARROS, J. A.; MEDEIROS, E. V.; COSTA, D. P.; DUDA, G. P.; LIMA, J. R. S.; SANTOS, U. J.; HAMMECKER, C. Human disturbance affects enzyme activity, microbial biomass and organic carbon in tropical dry sub-humid pasture and forest soils. Archives of Agronomy and Soil Science, v. 66, n. 4, p. 458-472, 2020.

BASHRI, G.; PATEL, A.; SINGH, R.; PARIHAR, P.; PRASAD, S. M. Mineral solubilization by microorganism: mitigating strategy in mineral deficient soil. Microbial Biotechnology, v. 1, n. 1, p. 265-285, 2018.

BATISTA, E. R.; CARNEIRO, J. J.; PINTO, F. A.; SANTOS, J. V.; CARNEIRO, M. A. C. Environmental drivers of shifts on microbial traits in sites disturbed by 
a large-scale tailing dam collapse. Science of the Total Environment, v. 725, e139453, 2020.

BLANCO-CANQUI, H.; SHAVER, T. M.; LINDQUIST, J. L.; SHAPIRO, C. A.; ELMORE, R. W.; FRANCIS, C. A.; HERGERT, G. W. Cover crops and ecosystem services: insights from studies in temperate soils. Agronomy Journal, v. 107, n. 6, p. 2449-2474, 2015.

BONETTI, J. D. A.; PAULINO, H. B.; SOUZA, E. D. D.; CARNEIRO, M. A. C.; CAETANO, J. O. Soil physical and biological properties in an integrated crop-livestock system in the Brazilian Cerrado. Pesquisa Agropecuária Brasileira, v. 53, n. 11, p. 1239-1247, 2018.

BOUYOUCOS, G. J. A recalibration of the hydrometer method for making mechanical analysis of soils. Agronomy Journal, v. 43, n. 9, p. 434-438, 1951.

BURNS, R. G.; FOREST, J. L.; MARXSEN, J.; SINSABAUGH, R. L.; STROMBERGER, M. E.; WALLENSTEIN, M. D.; ZOPPINI, A. Soil enzymes in a changing environment: current knowledge and future directions. Soil Biology and Biochemistry, v. 58, n. 1, p. 216-234, 2013.

CARNEIRO, M. A. C.; SOUZA, E. D.; REIS, E. F.; PEREIRA, H. S.; AZEVEDO, W. R. Atributos físicos, químicos e biológicos de solo de Cerrado sob diferentes sistemas de uso e manejo. Revista Brasileira de Ciência do Solo, v. 33, n. 1, p. 147-157, 2009.

CARVALHO, P. C. D. F.; PETERSON, C. A.; NUNES, P. A. D. A.; MARTINS, A. P.; SOUZA FILHO, W.; BERTOLAZI, V. T.; ANGHINONI, I. Animal production and soil characteristics from integrated crop-livestock systems: toward sustainable intensification. Journal of Animal Science, v. 96, n. 8, p. 3513-3525, 2018.

CECAGNO, D.; GOMES, M. V.; COSTA, G. A.; VALADÃO, S. E.; MARTINS, A. P.; DENARDIN, L. G. O.; CARVALHO, P. C. F. Soil organic carbon in an integrated crop-livestock system under different grazing intensities. Revista Brasileira de Ciências Agrárias, v. 13, n. 3, e553, 2018.

COMPANHIA NACIONAL DE ABASTECIMENTO (Conab). Observatório agrícola: acompanhamento da safra brasileira de grãos, 6 (6) - safra 2018/2019. 2019. Disponível em: https://www.conab.gov.br/component/k2/item/ download/25183_cb54effd57f6232cedcc6c0c7f53522a. Acesso em: 06 jun. 2020.

CONG, J.; YANG, Y.; LIU, X.; LU, H.; LIU, X.; ZHOU, J.; ZHANG, Y. Analyses of soil microbial community compositions and functional genes reveal potential consequences of natural forest succession. Scientific Reports, v. 5, n. 1, p. 1-11, 2015.

COUTO, G. M.; EISENHAUER, N.; OLIVEIRA, E. B; CESAR, Z. S.; FELICIANO, A. L. P.; MARANGON,
L. C. Response of soil microbial biomass and activity in early restored lands in the northeastern Brazilian Atlantic Forest. Restoration Ecology, v. 24, n. 5, p. 609-616, 2016.

DICK, R. P.; BREAKWELL, D. P.; TURCO, R. F. Soil enzyme activities and biodiversity measurements as integrative microbiological indicators. Methods for Assessing Soil Quality, v. 49, n. 1, p. 247-271, 1997.

EIVAZI, F.; TABATABAI, M. A. Glucosidases and galactosidases in soils. Soil Biology and Biochemistry, v. 20, n. 5, p. 601-606, 1988.

FERREIRA, D. F. Sisvar: a computer statistical analysis system. Ciência e Agrotecnologia, v. 35, n. 6, p. 10391042, 2011.

GUPTA, V. V. S. R.; ROPER, M. M.; THOMPSON, J.; PRATLEY, J. E.; KIRKEGAARD, J. Harnessing the benefits of soil biology in conservation agriculture. Wagga Wagga: Charles Sturt University, 2020.

HINOJOSA, M. B.; GARCÍA-RUÍZ, R.; VIÑEGLA, B.; CARREIRA, J. A. Microbiological rates and enzyme activities as indicators of functionality in soils affected by the Aznalcóllar toxic spill. Soil Biology and Biochemistry, v. 36, n. 10, p. 1637-1644, 2004.

HOFFMANN, R. B.; MOREIRA, É. E. A.; HOFFMANN, G. S. S.; ARAÚJO, N. S. F. Efeito do manejo do solo no carbono da biomassa microbiana. Brazilian Journal of Animal and Environmental Research, v. 1, n. 1, p. 168178, 2018.

HU, W.; JIAO, Z.; WU, F.; LIU, Y.; DONG, M.; MA, X.; FAN, T.; AN, L.; FENG, H. Long-term effects of fertilizer on soil enzymatic activity of wheat field soil in Loess Plateau, China. Ecotoxicology, v. 23, n. 10, p. 2069-2080, 2014.

JOERGENSEN, R. G.; BROOKES, P. C. Ninhydrinreactive nitrogen measurements of microbial biomass in $0.5 \mathrm{M} \mathrm{K}_{2} \mathrm{SO}_{4}$ soil extracts. Soil Biology and Biochemistry, v. 22, n. 8, p. 1023-1027, 1990.

KASCHUK, G.; ALBERTON, O.; HUNGRIA, M. Three decades of soil microbial biomass studies in Brazilian ecosystems: lessons learned about soil quality and indications for improving sustainability. Soil Biology and Biochemistry, v. 42, n. 1, p. 1-13, 2010.

LANGE, M.; HABEKOST, M.; EISENHAUER, N.; ROSCHER, C.; BESSLER, H.; ENGELS, C.; GLEIXNER, G. Biotic and abiotic properties mediating plant diversity effects on soil microbial communities in an experimental grassland. Plos One, v. 9, n. 5, e96182, 2014.

LANNA, A. C.; SILVEIRA, P. M. da; SILVA, M. B. da; FERRARESI, T. M.; KLIEMANN, H. J. Atividade de urease no solo com feijoeiro influenciada pela cobertura vegetal e sistemas de plantio. Revista Brasileira de Ciência do Solo, v. 34, n. 6, p. 1933-1939, 2010. 
LAROCA, J. V. D. S.; SOUZA, J. M. A. D.; PIRES, G. C.; PIRES, G. J. C.; PACHECO, L. P.; SILVA, F. D. D.; SOUZA, E. D. D. Qualidade do solo e produtividade de soja em sistema de integração lavoura-pecuária em plantio direto. Pesquisa Agropecuária Brasileira, v. 53, n. 11, p. 1248-1258, 2018.

LOPES, A. A. C.; SOUSA, D. M. G.; REIS JÚNIOR, F. B.; FIGUEIREDO, C. C.; MALAQUIAS, J. V.; SOUZA, L. M.; MENDES, I. C. Temporal variation and critical limits of microbial indicators in oxisols in the Cerrado, Brazil. Geoderma Regional, v. 12, n. 1, p. 72-82, 2018.

MANKOLO, R.; REDDY, C.; SENWO,Z.; NYAKATANA, E. E.; SAJJALA, S. Soil biochemical changes induced by poultry litter application and conservation tillage under cotton production systems. Agronomy, v. 2, n. 3, p. 187198, 2012.

MATSUOKA, M.; MENDES, I. C.; LOUREIRO, M. F. Biomassa microbiana e atividade enzimática em solos sob vegetação nativa e sistemas agrícolas anuais e perenes na região de Primavera do Leste (MT). Revista Brasileira de Ciência do Solo, v. 27, n. 3, p. 425-433, 2003.

MCLEAN, E. O.; HEDDLESON, M. R.; BARTLETT, R. J.; HOLOWAYCHUK, N. Aluminum in soils: I. Extraction methods and magnitudes in clays and Ohio soils. Soil Science Society of America Journal, v. 22, n. 5, p. 382387, 1958.

MEDEIROS, E. V.; DUDA, G. P.; SANTOS, L. A. R.; LIMA, J. R. S.; ALMEIDA-CORTÊZ, J. S. de; HAMMECKER, C.; COURNAC, L. Soil organic carbon, microbial biomass and enzyme activities responses to natural regeneration in a tropical dry region in Northeast Brazil. Catena, v. 151, n. 1, p. 137-146, 2017.

MEHLICH, A. Determination of $\mathrm{P}, \mathrm{Ca}, \mathrm{Mg}, \mathrm{K}, \mathrm{Na}$, and $\mathrm{NH}_{4}$. Raleigh: North Carolina Soil Test Division, 1953.

MENDES, I. C.; SOUSA, D. M. G.; REIS JUNIOR, F. B. Bioindicadores de qualidade de solo: dos laboratórios de pesquisa para o campo. Cadernos de Ciência \& Tecnologia, v. 32, n. 1/2, p. 191-209, 2015.

MENDES, I. C.; SOUZA, L. V.; RESCK, D. V. S.; GOMES, A. C. Propriedades biológicas em agregados de um Latossolo Vermelho-Escuro sob plantio convencional e direto no Cerrado. Revista Brasileira de Ciência do Solo, v. 27, n. 3, p. 435-443, 2003.

MENDES, I. D. C.; SOUSA, D. M. G.; REIS JUNIOR, F. B.; LOPES, A. D. C. Bioanálise de solo: como acessar e interpretar a saúde do solo. Planaltina, DF: Embrapa Cerrados, 2018.

MORAES, J. M. A. S.; ZANCHI, C. S.; PIRES, G. C.; MORETTI, C. F.; BARBOSA, M. V.; SILVA, A. O.; SOUZA, E. D. Arbuscular mycorrhizal fungi in integrated crop livestock systems with intercropping in the pasture phase in the Cerrado. Rhizosphere, v. 11, e100165, 2019.

PASSOS, S. R.; REIS JUNIOR, F. B.; RUMJANEK, N. G.; MENDES, L. C.; BATISTA, M. J.; XAVIER, G. R. Atividade enzimática e perfil da comunidade bacteriana em solo submetido à solarização e biofumigação. Pesquisa Agropecuária Brasileira, v. 43, n. 7, p. 879-885, 2008.

PETERSON, C. A.; EVINER, V. T.; GAUDIN, A. C. Ways forward for resilience research in agroecosystems. Agricultural Systems, v. 162, n. 1, p. 19-27, 2018.

PROBER, S. M.; LEFF, J. W.; BATES, S. T.; BORER, E. T.; FIRN, J.; HARPOLE, W. S.; CLELAND, E. E. Plant diversity predicts beta but not alpha diversity of soil microbes across grasslands worldwide. Ecology Letters, V. 18, n. 1, p. 85-95, 2015.

R DEVELOPMENT CORE TEAM. $R$ : a language and environment for statistical computing. 2019. Disponível em: https://www.r-project.org/. Acesso em: 01 fev. 2020.

ROLLER, B. R. K; SCHMIDT, T. M. The physiology and ecological implications of efficient growth. The ISME Journal, v. 9, n. 7, p. 1481-1487, 2015.

RYSCHAWY, J.; CHOISIS, N.; CHOISIS, J. P.; JOANNON, A.; GIBON, A. Mixed crop-livestock systems: an economic and environmental-friendly way of farming? Animal, v. 6, n. 10, p. 1722-1730, 2012.

SANTOS, U. J.; MEDEIROS, E. V.; DUDA, G. P.; MARQUES, M. C.; SOUZA, E. S. D.; BROSSARD, M.; HAMMECKER, C. Land use changes the soil carbon stocks, microbial biomass and fatty acid methyl ester (FAME) in Brazilian semiarid area. Archives of Agronomy and Soil Science, v. 65, n. 6, p. 755-769, 2019.

SARTO, M. V.; BORGES, W. L.; SARTO, J. R.; PIRES, C. A.; RICE, C. W.; ROSOLEM, C. A. Soil microbial community and activity in a tropical integrated croplivestock system. Applied Soil Ecology, v. 145, n. 1, p. $1-11,2020$.

SHIGYO, N.; UMEKI, K.; HIRAO, T. Plant functional diversity and soil properties control elevational diversity gradients of soil bacteria. FEMS Microbiology Ecology, v. 95, n. 4, p. 1-30, 2019.

SOLEIMANI, A.; HOSSEINI, S. M.; BAVANI, A. R. M.; JAFARI, M.; FRANCAVIGLIA, R. Influence of land use and land cover change on soil organic carbon and microbial activity in the forests of northern Iran. Catena, v. 177, n. 1, p. 227-237, 2019 .

SOUSA, D. M. G.; LOBATO, E. Cerrado: correção do solo e adubação. Planaltina, DF: Embrapa Cerrados, 2004.

SOUZA, E. D.; COSTA, S. E. V. G. A.; ANGHINONI, I.; CARNEIRO, M. A. C.; MARTINS, A. P.; BAYER, C. 
Soil quality indicators in a Rhodic Paleudult under long term tillage systems. Soil and Tillage Research, v. 139, n. 1, p. 28-36, 2014.

SOUZA, E. D.; SILVA, F. D.; PACHECO, L. P.; LAROCA, J. S. V.; SOUZA, J. M. A.; BONETTI, J. A. Matéria orgânica do solo em sistemas integrados de produção agropecuária no Brasil. In: SOUZA E. D.; SILVA F. D.; ASSMANN ,T. S.; CARNEIRO, M. C. C.; CARVALHO, P. C. F.; PAULINO, H. P. Sistemas integrados de produção agropecuária no Brasil. Tubarão: Copiart, 2018. p. 107-122.

STEWART, C. E.; FOLLETT, R. F.; PRUESSNER, E. G.; VARVEL, G. E.; VOGEL, K. P.; MITCHELL, R. B. $\mathrm{N}$ fertilizer and harvest impacts on bioenergy crop: contributions to SOC. GCB Bioenergy, v. 8, n. 6, p. 12011211, 2016.

STIEVEN, A. C.; OLIVEIRA, D. A.; SANTOS, J. O.; WRUCK, F. J.; CAMPOS, D. T. S. Impacts of integrated crop-livestock-forest on microbiological indicators of soil. Agrária, v. 9, n. 1, p. 53-58, 2014.
TABATABAI, M. A.; BREMNER, J. M. Distribution of total and available sulfur in selected soils and soil profiles. Agronomy Journal, v. 64, n. 1, p. 40-44, 1972.

TILMAN, D. Functional diversity. In: LEVIN, S. A. (ed.). Encyclopedia of biodiversity. San Diego: Academic Press, 2001. p. 109-120.

VANCE, E. D.; BROOKES, P. C.; JENKINSON, D. S. An extraction method for measuring soil microbial biomass. Soil Biology and Biochemistry, v. 19, n. 6, p. 703-707, 1987.

WALKLEY, C. A.; BLACK, I. A. An examination of Degtjareff method of determining soil organic matter and proposed modification of the method of the chromic acid titration method. Soil Science, v. 37, n. 1, p. 2939, 1934.

ZHOU, Y.; STAVER, A. C. Enhanced activity of soil nutrient-releasing enzymes after plant invasion: a metaanalysis. Ecology, v. 100, n. 11, e02830, 2019. 